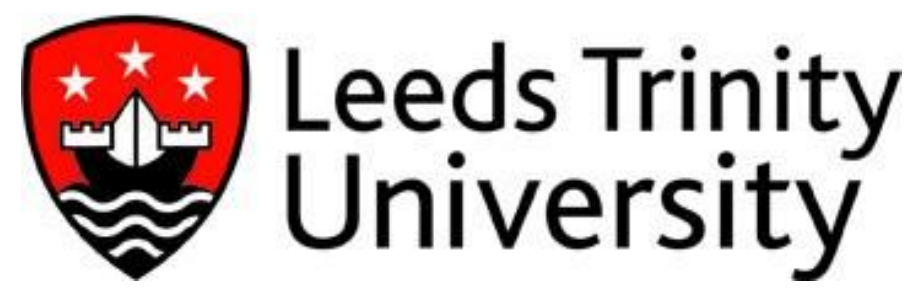

(C) The Author 2016. This is the author's version of the work. It is posted here for personal use, not for redistribution. The definitive version was published in Educational Theory, 66(4) pp. 519-534. http://dx.doi.org/10.1111/edth.12186

Fulford, A. 2016. Learning to Write: Plowing and Hoeing, Labor and Essaying. Educational Theory. 66(4) pp. 519-534. 


\section{Learning to Write: Plowing and Hoeing, Labor and Essaying}

\section{Amanda Fulford}

Leeds Trinity University, UK.

ABSTRACT

In this paper Fulford addresses the issue of student writing in the university, and explores how the increasing dominance of outcome-driven modes of learning and assessment is changing the understanding of what it is to write, what is expected of students in their writing, and how academic writing should best be supported. The starting point is the increasing use of what are termed 'technologies' of writing - 'handbooks' for students that address issues of academic writing - that systematize, and smooth the work of writing in, Fulford argues, an unhelpful way. This leads to a reconsideration of what it means to write in the university, and what it is to be a student who writes. Fulford explores etymologically the concept of 'writing', and suggests that it might be seen metaphorically as physical labor. Writing as physical labor is explored further through the agricultural metaphors in Henry David Thoreau's Walden, and through Stanley Cavell's reading of this text. In making a distinction between writing-as-plowing, and writing-as-hoeing, Fulford argues that some technologies of writing deny voice, rather than facilitate it, and concludes by offering a number of suggestions for the teaching and learning of writing in the university that emphasize the value of being lost (in one's subject, and one's work) and finding one's own way out. These 'lessons' are illustrated with reference to Thoreau's text of Walden, and from American literature and film.

\section{INTRODUCTION: TECHNOLOGIES OF WRITING}

This paper considers the student as 'writer' in the contemporary university. Writing, and academic writing in particular, is clearly under the spotlight, and the student in the university has arguably never had access to more detailed guidelines on what is expected, nor access to better support for writing. A whole industry now exists to produce these, what I call in this paper, 'technologies of writing'. This is evidenced by the production of text books and 'how to' guides explaining, from initiation to completion, the process of producing the report, the essay, the reflective account, 
dissertation or the thesis. Many of these are differentiated by academic level ${ }^{1}$ and by discipline area. ${ }^{2}$ Some even focus on particular elements of a larger piece of writing such as the literature review. ${ }^{3}$ Universities have also recognized the need to address student support in writing. Many institutions have developed their own dedicated academic writing websites as ancillary support, have introduced a range of measures including study skills support services, centres for academic writing, and have recruited specialist writing mentors. Academic writing in the contemporary university can thus be said to be 'technologized'. This needs some explanation: first, the use of this term recognizes that the development of students' academic writing skills, and the support for its ongoing development, is often mediated by technology. ${ }^{4}$ But the use of the term 'technologies' calls attention to a second phenomenon: the systematisation of academic writing, as evidenced in its definition in terms of skills and competencies against which students' writing can be measured through assessment, and for which they can be held to account. We might call these developments 'technologies of risk management'; they guide students to the product that passes the test, and that meets the learning outcomes. And managing risks in these ways is not just restricted to textbooks aimed at a student audience. To ensure new and early career researchers' success in delivering outputs, a plethora of guides promise a smooth path to writing, success through publication, ${ }^{5}$ and securing of grant funding. ${ }^{6} \mathrm{~A}$ further danger with such strict adherence to the formulae given in these kinds of text, is that they risk stripping out the thinking from the writing process. ${ }^{7}$ Perhaps a word of caution is needed here. In using the term 'technologisation' here, I am not offering a critique of the use of electronic or digital technologies to support the teaching and learning of academic

\footnotetext{
${ }^{1}$ See Dorothy Bedford and Elizabeth Wilson, Study Skills for Foundation Degrees, (Abingdon: Routledge, 2013).

${ }^{2}$ See Peter Redman and Wendy Maples, Good Essay Writing: A Social Sciences Guide, (London: Sage, 2011).

${ }^{3}$ See Diana Ridley, The Literature Review: A Step-by-Step Guide for Students, (London: Sage, 2012).

${ }^{4}$ See Mark Conroy, "Internet Tools for Language Learning: University Students Taking Control of their Writing", Australasian Journal of Educational Technology, 26, Issue 6, (2010): 861 - 882.

${ }^{5}$ See Laura Belcher, Writing Your Journal Article in Twelve Weeks: A Guide to Academic Publishing Success, (London: Sage, 2009).

${ }^{6}$ See Soraya Coley and Cynthia Scheinberg, Proposal Writing: Effective Grantsmanship, 4th edition, (London: Sage, 2014).

${ }^{7}$ For a fuller discussion of this point, see Amanda Fulford, "Ventriloquising the Voice: Student Writing in the University", Journal of Philosophy of Education, 43, No. 2, (2009): 223 - 237.
} 
writing per se, nor am I claiming that such technologisation is a new phenomenon, a characteristic emerging in postmodernity. Indeed, writing has always required the use of certain technologies, be these flints for scratching on rocks, styli for making marks on clay tablets, quills and pens for paper and parchment, or touch-screen and voice-activated technology in the digital age. In referring to the technologies of academic writing (and the technologisation that such tools bring), I am rather

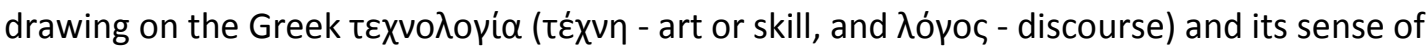
systematic treatment or technique.

Equipping students with the power to write academically is, though, surely one good and proper outcome of a university education. To consider what is at stake in embracing these new technologies of writing is, however, not to argue against supporting student writing in the university. The argument made here does not deny that there are distinctive practices of writing that are shared by members of academic traditions, nor that students should be inducted into how writing is typically pursued in the respective disciplines. This is not to advocate students' unlimited selfexpression, or to authorize an approach of 'anything goes'. Prescribed formal structures for forms of academic writing (as many of the handbooks provide) are not necessarily the problem. Indeed precise formal structure, such as the poetic forms of the sonnet or the haiku, can be the very medium for an intensification and release of thought. The aim here is rather to draw attention to two issues: first, that little thought tends to be given in these technologies to what it is to be a writer in more meaningful ways than in the simplistic categories described by Phyllis Crème and Mary Lea of the 'Diver', the 'Patchwork Writer', the 'Grand Plan Writer' and the 'Architect Writer'. ${ }^{8}$ Second, that the emphasis on the technologies of writing often fail to give sufficient attention to the work of writing, focussing instead on ensuring that writers have got the 'right "voice."' Of course we can see how students are attracted by this approach, its subtle assurances and its alluring promise. What I argue, though, is that such technologies fail to deliver the promised development of the 'academic

\footnotetext{
${ }^{8}$ Phyllis Crème and Mary Lea, Writing at University: A Guide for Students, 3rd edition, (Maidenhead: Open University Press, 2008).
} 
voice', and rather render the student voiceless. It is as if the utilisation of certain technologies acts as a kind of magic formula, an easy shortcut to avoid the (hard) work of developing a certain writing style, but more importantly of knowing what to say. It implies that academic writing in the disciplines consists of a formula, a set of 'tricks'; that a student achieves voice in her written work in a way that entails simply the mastering of a certain set of skills that commonly pass for academic writing.

One characteristic of many technologies of academic writing is that they attend mainly to technical aspects of writing - to the development of skills in particular - that decontextualize writing and strip students of their voice and identity as writers. ${ }^{9}$ The creeping orthodoxy of such approaches might be attributed to two key factors. First, Higher Education has seen the broadening of the curriculum, in some contexts, to include vocationally-oriented and professional training courses that attract 'non-traditional' entrants who often seek support with the practices of formal academic writing. Second, the pervasive culture of learning outcomes, and of student satisfaction league tables, drive a raft of measures - including the use of technologies of writing - to ensure and thereby raise student achievement. In the textbook technologies of academic writing in particular, a systematic approach that tends to be encouraged. Take this as an example from a popular textbook for students titled Writing for Academic Success where the skills of academic writing appear as something of a given:

By applying the strategies, doing the exercises, and following the procedural steps in this chapter, you should be able to...renew your acquaintance with standard academic writing practices...and identify strategies to ensure clarity in writing, conciseness and appropriate use of voice and tone. ${ }^{10}$

\footnotetext{
${ }^{9}$ Roz Ivanič, "Discourses of Writing and Learning to Write", Language \& Education: An International Journal, 18 Issue 3, (2004): 220 - 245.

${ }^{10}$ Gail Craswell and Megan Poore, Writing for Academic Success, 2nd edition, (London: Sage, 2013), 56.
} 
The systematisation to which I draw attention is amply illustrated in the quotation above, and is found extensively in the language of support material for academic writing more generally. But if what constitutes 'good academic writing' is articulated, and reinforced through these media, then it is even further prescribed in university assessment criteria that tend to lay out the specific technical aspects of writing that need to be evidenced to achieve a grade of pass, merit, or of distinction. The establishment of sets of criteria against which competence or achievement in academic writing can be measured and monitored, is further evidence of both the technologisation of writing, and of the individual writer who is situated in particular ways by them. Of course, academic writing has always been a kind of restricted writing - a 'hegemony of the mundane'11 - in comparison with, for example, literary forms such as fiction or poetry. But the strength and extent of its restriction is seen in criteria for academic writing that take little account of context or content, but rather tend to focus, almost exclusively, on the technical aspects of the writing. These include aspects such as genre and grammar, organisational features such as sentence structure and paragraphing that contribute to fluency, persuasiveness, and coherence, and above all, specific conventions such as citation, quotation, and referencing. In all this, there is a tendency to see writing as a process in need of demystification. In some ways, the burgeoning industry of writing technologies celebrates and feeds a certain mystique around academic writing on which, they claim, their products shed light. As a result, there is a move to deconstruct writing, only to reconstruct it as a series of linear processes that, if followed systematically, leads to the model output. Thus, writing that unthinkingly follows the procedural steps in the writing handbook has come to epitomize what writing is, what academic writing means. In this process the writer is passive, merely following a set of instructions that blind her to her task as an author. This task is perhaps clearer if we consider the roots of the word 'author' in the Latin augere meaning to promote or originate, and the Old French acteor (creator, instigator, one who causes to grow). Perhaps the etymological link between 'author' and 'auth-entic' reveals

\footnotetext{
${ }^{11}$ Jodi Kearns, Brian O'Connor and Francisco Moore, "Provocations of the Structure of Scholarly Writing in the Digital Era”, On the Horizon, 15, Issue 4, (2007): 222.
} 
something important about the task of writing that goes beyond the strictures of the proceduralized route to the model essay, report, reflective account, or journal article. It also suggests that writingauthoring is also about the creation of the self.

The emphasis in many technologies of academic writing is a focus on the output, the final product, and support often proceeds according to a well-rehearsed, and often prescriptive formula of mapping ideas, creating a draft, editing, re-writing, and final proof reading. ${ }^{12}$ Writing tends to be conceived as a stage to be completed once one's thinking is done; it is just a case of 'writing up'. But writing is messier than this; thinking and writing cannot easily be separated. As Paul Standish notes: 'Sometimes you don't know what you think until you have written it. ${ }^{13}$ But Craswell and Poore's text reinforces a staged approach to writing for academic success, stating that it requires 'improving your management of multiple communication tasks...considering procedural steps well in advance ${ }^{\prime}{ }^{14}$ and 'sequential outlining' to ensure that you 'gain control over [content] coverage', and for 'determining the logic of [topic] relations' ${ }^{\prime 15}$ Handbooks such as these can be understood as facilitating a kind of self-expression, especially amongst those from non-traditional backgrounds. But these modes of expression are channelled in ways that are of a piece with other contemporary forms of what is supposed to be student-centeredness, all of which aim to enhance the overall student experience, and to drive up achievement. ${ }^{16}$ It is perhaps not too strong a description to say that these approaches, along with the rigid use of certain technologies of academic writing, are - to use Bert Lambeir and Stefan Ramaekers' words - 'a form of terror with respect to learning and knowing'. ${ }^{17}$

\footnotetext{
12 Stephen Bailey, Academic Writing: A Handbook for International Students, (Abingdon: Routledge, 2006).

13 Paul Standish, "What Is the Philosophy of Education?", in The Philosophy of Education: An Introduction, ed. Richard Bailey, (London: Continuum, 2010), 11.

${ }^{14}$ Craswell and Poore, Writing for Academic Success, 15.

${ }^{15}$ Craswell and Poore, Writing for Academic Success, 75.

${ }^{16}$ For further examples, see Elizabeth Staddon and Paul Standish, "Improving the Student Experience", Journal of Philosophy of Education, 46, No. 4, (2012): 631 - 648.

${ }^{17}$ Bert Lambeir and Stefan Ramaekers, "The Limits of 'Blackboard' are the Limits of My World: On the Changing Concepts of the University and its Students", E-Learning, 3, No. 4, (2006): 547.
} 


\section{WRITING: SCRATCHING OUT AND CARVING IN}

This paper now turns to consider what it is to be a student who writes, and drawing on the etymology of the word 'write,' explores the work of the writer, metaphorically, as physical labor. Etymologically, the modern usage of 'write' is derived from the Old English and the Saxon writan meaning 'to score' or 'to tear', and the Old Norse word rita meaning 'to scratch' or 'to carve out'. In most Indo-European languages, 'write' is also related to words meaning 'to carve' or 'scratch out'. To

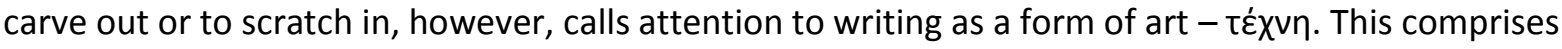
not only the practical skill required for such a craft, but also the underlying knowledge and experience required to undertake and produce it. ${ }^{18}$ The Greek $ү \rho \alpha \dot{\phi} \phi \varepsilon \mathrm{v}$, the German schreiben, and the French écrire are also all etymologically related to ideas of carving or engraving. The connotations of these terms clearly relate to the ancient origins of writing where physical effort was needed to carve out, or to dig into stone or clay, the required letters, symbols and words,. As the tools of writing have changed, so too has the physical effort required. For example, the effort needed to make marks with a hammer and chisel, with quills on parchment, or with pencils, fountain pens and biros on paper, is clearly not the same. With the advent of digital technologies, the physical pressing of the keys of the typewriter and the use of the carriage return, has been replaced by almost silent keys on our computers and laptops. Most recently, noiseless touch screen technology has been developed that is operated by the slightest physical touch, or swipe, and often doesn't require us to touch each letter of a word, but predicts it for us. A further development has been the introduction of technology that uses voice-activated software, removing the need for any hand-held implement or hand-operated tools for writing. Still more recently, the use of eye tracking computer devices allows individuals with significant disabilities to communicate through the translation of eye movements across alphabetic panels to recreate text - writing - on a screen. ${ }^{19}$ The advent of such

\footnotetext{
${ }^{18}$ This point is made in Stephen Halliwell's book, Aristotle's Poetics, (Chicago: University of Chicago Press, 1998).

${ }^{19}$ R. Spataro, M. Ciriacono, C. Manno, and C. La Bella, "The Eye-Tracking Computer Device for Communication in Amyotrophic Lateral Sclerosis", Acta Neurologica Scandanavia, 130, Issue 1, (2014): 40 - 45.
} 
significant electronic and digital technologies has not removed the discussion of the physical aspects of writing in the research literature, but rather changed its emphasis. In the first decades of the twentieth century, attention was given mainly to issues of penmanship, ${ }^{20}$ how to teach handwriting, ${ }^{21}$ and particularly on scoring legibility. ${ }^{22} \mathrm{~A}$ century later, the physical aspects of handwriting are now discussed more in relation to issues of gross and fine motor skills and coordination, ${ }^{23}$ so-called 'muscle memory', ${ }^{24}$ and ergonomics including pen design and grip, paper angle and furniture layout. ${ }^{25}$ So, in summary, whilst developments in the tools for writing have undoubtedly altered - and decreased - the physicality of the act of writing, the latest research seems to re-focus attention on some of the physical aspects of the writing task. But the main concern of this paper is not to pursue these aspects in terms merely of 'what works', but to ask what can be gained in thinking metaphorically of writing as physical labor. How might this kind of thinking counter the discourses of the technologies of writing that seek to construct the writer, and writing itself, in ways that deny its inherent messiness, complexity, and the transformation of the self that comes through continued attention to learning to do it?

\section{WRITING AND HOEING: THOREAU AND WRITING AS PHYSICAL LABOR}

In his book Walden, ${ }^{26}$ Henry David Thoreau, the nineteenth century transcendentalist author and philosopher, writes of living at Walden Pond in Concord, Massachusetts, and of the way he spent his

\footnotetext{
${ }^{20}$ G.M. Wilson, "The Handwriting of School Children", Elementary School Teacher, 11, Issue 10, (1911): 540 - 543.

${ }^{21}$ Frank Freeman, "Current Methods of Teaching Handwriting'" Elementary School Teacher, 12, Issue 10, (1912): 481 - 493.

22 Leonard Ayers, Scale for Measuring the Quality of Handwriting in School Children, (New York: Russell Sage Foundation, 1912).

${ }^{23}$ Jérémy Danna, Fabienne Enderli, Sylvie Athenes, and Pier-Giorgio Zanone, "Motor Coordination Dynamics Underlying Graphic Motion in 7- to 11-Year-Old Children", Journal of Experimental Child Psychology, 111, No. 1, (2012): $37-51$.

${ }^{24}$ Stephen Grossberg and Rainer Paine, "Neural Model of Cortico-Cerebellar Interactions during Attentive Imitation and Predictive Learning of Sequential Handwriting Movements", Neural Networks, 13, Nos 8-9, (2000): 999 - 1046.

${ }^{25}$ Turan Temur, "Description of Primary Education 1st Grade Students' Forms of Holding a Pencil as well as Their Grip and Compression Strengths", Educational Sciences: Theory and Practice, 11, No. 4, (2011): 2199 2205.

${ }^{26}$ Henry David Thoreau, Walden, (Oxford: Oxford University Press, 1854/1999).
} 
time: building his hut, laboring in the fields planting and tending his beans, visiting the pond, observing and recording nature and the seasons, and writing. Thoreau writes this:

After hoeing, or perhaps reading and writing, in the forenoon, I usually bathed again in the pond, swimming across one of its coves for a stint, and washed the dust of labor from my person, or smoothed out the last wrinkle which study had made, and for the afternoon was absolutely free. ${ }^{27}$

At first glance, we might read this excerpt as saying that in the mornings, Thoreau would work, perhaps spending time hoeing (his beans) or reading and writing. But another possible reading is this: that the very physical work of hoeing is a way of thinking about reading and writing; so the line would read as: 'After hoeing (that is, after reading and writing)...I washed the dust of labor from my person'. Both readings are suggestive of the work of writing, but the latter highlights the physical labor that is writing. This use of metaphor in Thoreau's writing, as well as his use of puns and allegories, is highlighted in Stanley Cavell's reading of Thoreau in his book The Senses of Walden. The work of writing Walden is in discovering what writing is. 'It takes a while to recognize', claims Cavell, 'that every word in which he [Thoreau] identifies himself or describes his work and his world is the identification and description of what he understands his literary enterprise to require ${ }^{\prime 28}$ If this is the case, then Walden, with its lengthy sections describing the physical labor of building his hut, and growing and harvesting his beans, is a text on the work of writing, a task that he describes in his chapter titled 'The Bean Field' as a 'small Herculean labor'. ${ }^{29}$ But this idea of the work of writing described in relation to ideas of the physical labor of working the land and of producing a crop - is also found elsewhere in Thoreau's writings. In his journal (for which extracts remain from 1837 through to 1862), Thoreau's writes this in his entry for 1847 :

\footnotetext{
27 Thoreau, Walden, 151.

${ }^{28}$ Stanley Cavell, The Senses of Walden, (San Francisco: North Point Press, 1981).

29 Thoreau, Walden, 140.
} 
From all points of the compass, from the earth beneath and the heavens above, have come these inspirations and been entered duly in the order of their arrival in the journal. Thereafter, when the time arrived, they were winnowed into lectures, and again, in due time, from lectures into essays. ${ }^{30}$

For the modern reader of Thoreau's text, familiar perhaps with highly mechanized, massscale farming practices that rely on sophisticated agricultural machinery, these metaphors of a man, toiling on the land with simple tools, are all the more powerful. But this does not suggest a bucolic reading of the text. Thoreau is not presenting an agrarian idyll. What the text does inform is a contemporary understanding of what it is to write, using Walden's images of plowing, hoeing and the physical labor that these tasks entail. To use such an agricultural analogy as a form of practical wisdom for understanding the work of writing may seem unusual, too straightforward, or even romantic or nostalgic. But a closer reading of what is at stake in Thoreau's account of tending his bean field, serves to illustrate its importance - and relevance. So let us return to Thoreau's use of the hoeing metaphor here, since it is important in a number of ways. Just as the hoe cuts into the soil, so writing is a kind of cutting - of the ideas onto the page - and calls to mind the etymology of the word. But hoeing not only involves the cutting of the blade into the ground; it is also a turning of the clods, an exposing of fresh soil to the glare of the sunlight. Thoreau writes:

As I drew a still fresher soil about the rows with my hoe, I disturbed the ashes of unchronicled nations ... When my hoe tinkled against the stones, that music echoed to the woods and the sky, and was an accompaniment to my labor which yielded an instant and immeasurable crop. It was no longer beans that I hoed. ${ }^{31}$

\footnotetext{
${ }^{30}$ Carl Bode, ed., The Best of Thoreau's Journals, (Carbondale: Southern Illinois University Press, 1967), 88.

${ }^{31}$ Thoreau, Walden, 143.
} 
So here, the act of writing is one of cutting and dividing words, of exposing ideas so that readers are themselves exposed to the cutting characteristics of words. That writing 'disturbs the ashes' suggests that it draws on tradition, and on forms of expression that Thoreau did not even know were there in him to write. ${ }^{32}$ Stanley Cavell, in his Senses of Walden, writes this of Thoreau's text:

Hoeing serves the writer as a trope - in particular, a metaphor for writing...The overarching parable of the chapter on "The Bean Field" is one that describes the writer-hoer most literally, one which itself takes harrowing to be (a metaphor of) the effect of words...He [Thoreau] links these two labors of the hand..$^{33}$

Thoreau draws attention to the importance of attending to the words that he uses when he writes: 'Books must be read as deliberately and reservedly as they were written' ${ }^{34}$ So, we need to consider what Thoreau's hoeing consists in. For Thoreau, hoeing is not plowing (the systematic lifting and turning of the soil in a regular pattern). Nor is it furrowing (the forming of regular trenches in the soil to prepare it for sowing). The operations of plowing and furrowing suggest a regularity, proceeding according to a prescribed pattern, the production of neat rows (like lines of writing on the page). Hoeing is also not (in the agricultural sense) the same as harrowing - the systematic breaking up and smoothing out of the surface of the soil to make a finer finish that makes undertaking subsequent tasks easier. Yet, there is a paradox here: hoeing is harrowing when thought of in relation to our words. For Cavell, the effect of our words is harrowing in that we are disturbed by them; Cavell would say that we are sentenced to, and by, them. ${ }^{35}$ Thoreau's hoeing (both in the field, and in

\footnotetext{
${ }^{32}$ The idea of our drawing on tradition in language is found in Thoreau's account of his borrowing an axe to cut down trees for the construction of his hut at Walden Pond, and how he returned the axe sharper than when he borrowed it. Cavell shows how this account serves as a metaphor for the way that we use language. We use the words that we inherit, that are passed down to us (that we 'borrow'), but our father tongue responsibility to words is to use them in a way that passes then back sharper to the community (Thoreau, Walden, 38).

${ }^{33}$ Cavell, Senses, 22.

${ }^{34}$ Thoreau, Walden, 92.

${ }^{35}$ In Cavell's Senses of Walden, he includes chapters titled 'Words' and 'Sentences'. There is a pun here: Cavell is not merely referring to grammatical elements of language here; he is also drawing attention to our relationship with language, and to how we are convicted by our words. He writes: 'To read a text accurately is to assess its computations, to check its sentences against our convictions' (p. 65). See also the discussion later in the paper on Cavell's discussion of the father tongue in Thoreau's Walden.
} 
writing), is a different kind of labor. Here, the hoer takes the tool and selects which beans to hoe, where to dig the blade into the soil, and to what depth. The hoer cultivates the crops, choosing where to loosen or to compact the earth and where to dig out choking weeds. Of course, this is not to suggest too strict a binary between plowing and hoeing; it is in straight lines that, in the end, we write things down. It is rather that the metaphor of the writer as hoer draws attention to the choices that are before the writer in terms of the words she chooses, and so what she causes to grow - or authors.

But how does this help us to think of writing, and of academic writing in the university in particular? A comparison can be drawn between the ordered and standardized - even mechanistic procedures of plowing, furrowing, and harrowing, and the technologies of academic writing that seek to bear the weight of the work, to prepare the ground, and make easy and smooth the work of writing. The plow, used in the field, eases (to some extent) the farmer's physical labor in cutting the earth. But plowing requires not only the farmer, but also the beast; and it is the animal in front that bears the weight, and it is there that the labor is felt. The regularity of the furrow that the plow assures makes for more efficient sowing and harvesting - and these are good things in the agricultural context. A steady pace and an even rhythm can be maintained given the affordances that plowing technology can bring, and hence, much ground can be covered. This is in contrast to the much slower pace that comes with the hoeing, because the hoer feels the full physical effort required to do the work. Here, the work may proceed by way of short bursts of intensive activity, and then periods of reflection - a looking around at the ground to see where to hoe next, and where to leave the earth uncut. But when technologies of academic writing rely on tools that produce only effective, neat patterning, they smooth the ground, and bear the weight of the work in a way that fails to recognize the complexity and messiness of the task.

When the skill required in writing is merely that of following the prescribed path to achieve the uniform end result, then something of writing, and what it is to be a writer, is lost. But in hoeing, 
the hoer chooses where to cut into the earth, to till and scrape the soil, and which of the weeds to eradicate. Similarly, to be a hoer-writer is to be one who has responsibility for which words to use, how they should be put together, what should be worked, and re-worked, and what should be weeded out. This is labor of writing where the writer, as the hoer 'makes such invidious distinctions with his hoe, levelling whole ranks of one species, and sedulously cultivating another' ${ }^{36}$

\section{WRITING AND LABORING: PEDAGOGICAL LESSONS}

All this is not to argue against the accepted conventions of different genres of writing, or to avoid teaching these to students. Without accepting certain patterns and conventions in writing, such as in the essay, the form of expression is frustrated. It is to argue, however, that there is a tendency in some technologies of writing to reduce it to an unthinking adherence to these schemas in a way that simplifies and sanitizes writing, and positions the writer as a mere puppet in the process. Of course, not all technologies are like this. Even when using a tool such as a plow, it is the blades that cut and work the ground, not the plower, but the responsibility for using the tool remains the plower's, and it is his work in the end. However, what some technologies of academic writing seem to avoid is the idea that writing is labor - often difficult labor - and the work of the writer is in the recognition of her responsibility to the words she cultivates and brings to the surface, and to those she discards. As Duck-Joo Kwak says of writing the essay: 'This is not just about "writing styles", self-consciously taught, but about possibilities of learning, thinking and being' ${ }^{37}$ It is as if writing itself, in some senses, produces the writer. Just as the hoer divides and tills the earth to bring forth life, so the labor of the writer consists in being awake, and being awoken to, the dividing possibilities of the words she uses; so Cavell writes:

\footnotetext{
${ }^{36}$ Thoreau, Walden, 145.

37 Duck-Joo Kwak, “Practising Philosophy, the Practice of Education: Exploring the Essay Form through Lukács' Soul and Form", Journal of Philosophy of Education, 44, No. 1, (2010): 63.
} 
Perhaps it will happen by a line of words so matured and experienced that you will see the sun glimmer on both of its surfaces, as if it were a scimitar, and feel its sweet edge dividing you through the heart. ${ }^{38}$

So if we take seriously the hoeing metaphor for writing and the physical labor that this entails, then a number of lessons for teaching and learning writing in the university follow. These, outlined below, go beyond discussing where support for writing should begin and end, as if there were some kind of continuum. They focus instead on what can be learned about learning to write, and the teaching of writing, from attention to the task itself, and from the pedagogical relationship and the encounter between tutor and student.

\section{(i) THE REPETITIVENESS OF THE LABOR}

First, writers and tutors must recognize the repetitiveness of the labor. Against the simple linear process suggested by some of the technologies of writing, to write is to give attention repeatedly to the task; there are no easy shortcuts. Weed killer (a shortcut, perhaps, to an easily managed and harvested crop), when applied to soil in appropriate quantities, will kill and prevent more choking weeds from growing. But an excess makes the soil less fertile; it renders it toxic. So in a similar way, an excess of some kinds of technologies of writing (and this is not to deny entirely their usefulness) does not necessarily make for a better crop of writing. Just as weeds keep coming up and the earth dries out and needs hoeing, so writing needs ongoing attention and re-working; it is through this kind of labor that the earth is harrowed and that writing is cultivated. Writing in this sense is a kind of testing: a repeated assessment of the effectiveness of our words. Thoreau, considering the writing of Walden, says: 'It will bear some iteration in the account, for there was no little iteration in the labor'. ${ }^{39}$ But this idea appears not only in Walden, but also elsewhere in Thoreau's writings. In his

\footnotetext{
${ }^{38}$ Cavell, Senses, 17.

39 Thoreau, Walden, 145.
} 
journal entry, for example, for February $28^{\text {th }} 1841$, he writes this: 'Nothing goes by luck in composition. It allows no tricks...Every sentence is the result of a long probation' ${ }^{40}$

\section{(ii) USING TECHNOLOGIES}

Second, there is a lesson from Thoreau's experience of cultivating his bean field using very few aids, or technologies. In his account in Walden of his work on the bean field, Thoreau writes: 'As I had little aid from horses or cattle, or hired men or boys, or improved implements of husbandry, I was much slower, and became much more intimate with my beans than usual'. ${ }^{41}$ So what does this say about the process of writing in general, and what light does the use of tools or technologies shed on academic writing in particular? It is not that we should be nostalgic for some kind of pretechnological golden era, or that we should eschew technology per se. The issue here is not with whether or not we should use technologies to support the development of academic writing; it is rather concerned with which technologies we use, and how. Some technologies that are helpful enable writers to see language as something that needs to be worked on - labored at. Other technologies suggest language as something that needs to be put in its (correct) place; such technologies are ones that not only divide us from our words, but also from our world. A reliance on the tools and technologies of writing (that lead to an unthinking, or strict, adherence to the handbook guidelines) separates us from the work of writing itself. Thoreau seems to be advocating a closeness to our writing, the value in being forced to confront it and to cultivate it through the sheer 'labor of the hands...pursued to the verge of drudgery'.$^{42}$ But what particular merit is there in this approach? Thoreau writes that when he continued to plant where others had begun to hoe, this elicited different forms of criticism and comment from his neighbours: 'Why is there no manure in the furrow?' 'Consider a little ash or plaster for the beans', 'This field bears no comparison with the crop from the neighbouring ones'. But for Thoreau, making these choices himself brought him closer

\footnotetext{
${ }^{40}$ Bode, Journals, 58.

41 Thoreau, Walden, 141.

42 Thoreau, Walden, 142.
} 
to his work. And this had one distinct advantage, as he says: 'I came to know how I stood in the agricultural world'.$^{43}$ So for students, the closeness to their own writing that is as the result of the labor of confronting it and having to make decisions about it without the prescription that certain technologies bring, allows them to know where they stand in their own particular academic field.

\section{(iii) BEING LOST AND FINDING ONESELF}

Third, we should take seriously how we allow students to be lost in the task of writing. When certain technologies of writing promise to demystify it, to provide a quick fix, to smooth the way, or to guarantee success, something important is pushed aside. What the technologies of writing generally, and outcome-driven approaches in Higher Education in particular, both fail to acknowledge, is what can be gained from being engrossed - or lost - in an endeavour. These are experiences of which Thoreau writes: 'It is a surprising and memorable, as well as a valuable experience, to be lost in the woods any time...Not till we are lost, in other words, not till we have lost the world, do we begin to find ourselves and realize where we are and the infinite extent of our relations' ${ }^{44}$ It is sometimes only when you are totally engaged in the activity, taken over by it - when you begin to write - that you know what it is you want to say, or are able to write. This idea of being taken over is one of which Cavell writes in relation to language more broadly. In his reading of Walden, he takes up Thoreau's reference to our relationship with language, and to the distinction that Thoreau draws between what he refers to as the mother tongue and the father tongue in language..$^{45}$ Thoreau associates the mother tongue with the naturalness and familiarity of our spoken language. But he contrasts this with what he terms the father tongue, most often associated with the written word. Thoreau writes:

\footnotetext{
${ }^{43}$ Thoreau, Walden, 142,

44 Thoreau, Walden, 154.

${ }^{45}$ Cavell, Senses, 15-16.
} 
It is not enough even to be able to speak the language...for there is a memorable interval between the spoken and the written language, the language heard and the language read. The one is commonly transitory, a sound, a tongue, a dialect merely, almost brutish, and we learn it unconsciously, like the brutes, of our mothers. The other is the maturity and experience of that; if that is our mother tongue, this is our father tongue, a reserved and select expression, too significant to be heard by the ear, which we must be born again in order to speak. ${ }^{46}$

Acquisition of the mother tongue is a necessary part of our initiation into the language community. But the familiarity that is so central to the mother tongue is also its potential danger: that it nurtures, as Naoko Saito claims, 'a state of conformity of the self to itself, and to language'. ${ }^{47}$ In contrast, the father tongue signals a relationship to our words that is characterized by a kind of disorientation, a distance from the native language for which Cavell claims that a transformation akin to a re-birth - is required. Encountering the father tongue in language is our being taken over by words, and our having to find our place within them again. There is no sense of the authoritarian here, or of the priority of the father tongue over the mother tongue. Saito puts it like this: 'We need both an initiation into and departure from the language community'. ${ }^{48}$ Being taken over by words being lost in them, or stopped in our tracks by them - is an invitation to us to re-consider our words to find our own voice.

But it is not only 'lost' in the sense of absorption in one's task, and in the written word, that can be understood from Thoreau's writings. What is also at stake is how one finds oneself again. Thoreau considers this when he writes (literally and metaphorically) of staying late in town and then of finding his way home [at night]:

\footnotetext{
46 Thoreau, Walden, 93.

${ }^{47}$ Naoko Saito, "Perfectionism and the Love of Humanity: Democracy as a Way of Life after Dewey, Thoreau, and Cavell", The Journal of Speculative Philosophy, New Series, 20, No. 2, (2006): 98.

${ }^{48}$ Saito, "Perfectionism", 99.
} 
It was very pleasant to launch myself into the night...I frequently had to look up at the opening between the trees above the path in order to learn my route, and, where there was no cart-path, to feel with my feet the faint track I had worn, or steer by the known relation of particular trees which I felt with my hands'. ${ }^{49}$

There is something very physical about finding your way here; something about feeling your way and setting your own markers that brings you closer to the task in a way that an aid such as a map would not. In the same way, learning how to write might be more educative if it sometimes involves being lost, and finding one's own way out. These ideas are beautifully illustrated in a scene from the American author, John Williams', novel, Stoner..$^{50}$ The central character, William Stoner, leaves his humdrum life on his parents' farm, to enter university to study agriculture. He finds little difficulty with the work in classes such as soil chemistry, but in compulsory classes on English literature Stoner's reaction is markedly different. The texts he is introduced to 'troubled and disquieted him in a way nothing had ever done before'. ${ }^{51} \mathrm{He}$ is introduced to Shakespeare's Sonnet 73 . The instructor, Archer Sloane, asks Stoner directly the meaning of the sonnet. He cannot reply. Sloane reads the sonnet aloud, and asks the question of Stoner again. Stoner is entirely absorbed in the question, aware only of the light streaming through the windows in the room, the shadows cast, and the tension in his tightly-gripped fingers. He is seduced by the question, and by the text of the sonnet, to the extent that he is unable to articulate the response immediately: "It means", he said and with a small movement raised his hands up toward the air; he felt his eyes glaze over as they sought the figure of Archer Sloane. "It means", he said again, and could not finish what he had begun to say'.52 Stoner's labor in this scene, and in the subsequent weeks until his decision to change his major to literature, is in being absorbed in his task; in finding his own way.

\footnotetext{
49 Thoreau, Walden, 153.

50 John Williams, Stoner, (London: Vintage Books, 1965/2012).

${ }^{51}$ Williams, Stoner, 8.

52 Williams, Stoner, 12.
} 


\section{(iv) FINDING VOICE, AND THE ROLE OF THE TUTOR}

The role of the tutor in supporting the development of students' writing, is, of course, a crucial one. Allowing students to be lost, and to find their own way does not abrogate the tutor from her responsibilities. To consider what the tutor's role might properly consist in, I turn to a second scene, this time from the 1944 Hollywood film, Gaslight, a film about which Cavell has written, most notably in his 1996 book Contesting Tears: The Hollywood Melodramas of the Unknown Woman. ${ }^{53}$ Directed by George Cukor, the film portrays Paula, a young woman, and the niece of a murdered opera singer, Alice Alquist. The naive young Paula is seduced by the accompanist for her singing lessons, Gregory Anton, and they subsequently marry. Crucial to the plot is the fact that Gregory, unbeknown to Paula, is her aunt's murderer. Gregory, driven by the knowledge that Paula's aunt owned valuable jewels, persuades Paula to make their home in her aunt's old house in London so that he can secretly search for the jewels for his own gain. To this end, he needs Paula out of the way and, through manipulation and deceit, sets out to convince Paula of her own madness, a ploy that, if successful, will have her taken away. Gregory's tactics seem to work; Paula begins not to trust her own judgement, and we gradually see her loss of her reason, and the loss of her physical and metaphorical voice. Paula is hysterical at the noises she hears from the attic, and the intermittent dimming of the gas lights in the house (all because, unknown to her, her husband is frantically searching the attic for the jewels). A local detective, Cameron, recognizes Paula as she bears a striking resemblance to her aunt, whose murder case he investigated years before. He becomes suspicious of Gregory's comings and goings in night hours (to gain access to the attic though a secret external entrance). He suspects that Paula's demise is related to Gregory's strange behaviour, and takes it upon himself to help in some way. In the final scenes of the film, Cameron gains access to

\footnotetext{
${ }^{53}$ Stanley Cavell, Contesting Tears: The Hollywood Melodrama of the Unknown Woman, (Chicago: The University of Chicago Press, 1996).
} 
the Anton house, and finds Paula, now in what Cavell calls the 'haunting of her existence'. ${ }^{54}$ She seems unable to speak, not from any kind of aphasia, but from an inexpressiveness - an inability to say how things are for her. ${ }^{55}$ Cameron seeks to facilitate Paula's recovery of voice, not by imposing a script - or we might say a technology of speaking - but by acting more as a voice coach, to enable Paula to find her own words. Cameron facilitates Paula's recovery - her awakening - by letting her find her voice, her own way with words, and in this she is aided by his promptings. Her recovery is through conversation, a turning of her thoughts such that what she voices is her conviction that the noises in the attic that have nearly driven her to derangement are those of her husband, madly searching for Alice Alquist's jewels. In a climactic scene towards the end of the film, the dialogue between Cameron and Paula runs like this:

Cameron Mrs. Anton, you know, don't you. You know who's up there?

Paula No, no.

Cameron Are you sure you don't?

Paula No, no. How could he be?

There are two aspects of Cameron's interaction with Paula that are worth drawing attention to in this context. First, Cameron makes no attempt to determine the form of Paula's speech through offering her a new script - say, a kind of salvation story - but allows her to arrive at her own words. Second, the marker of Paula's recovery of voice that is spoken in a scene shortly after this one, what Cavell terms her 'cogito ergo sum', ${ }^{56}$ is announced in her own words. When she announces to

\footnotetext{
${ }^{54}$ Stanley Cavell, Cities of Words: Pedagogical Letters on a Register of the Moral Life, (Cambridge MS: The Belknap Press of Harvard University Press), 13.

${ }^{55}$ Cavell signals a broader issue than simply the loss, and recovery, of voice at an individual level. One aspect of his rich conception of the term is how he sees voice as part of his own philosophical project - and how some forms of philosophy have repressed voice. For Cavell, voice is also political; it is central to his discussions of to what we give, or refuse, our consent, and so to criteria in language. These ideas also relate to Walden, and to how Thoreau's task, both in his time at Walden Pond and in writing the text, was to put his words to the test of his community, to account for himself.

${ }^{56}$ Cavell, Contesting Tears, 47.
} 
Cameron 'I want to speak to my husband. I want to speak to him alone', the double meaning of 'alone' - that is, 'to my husband only', and 'on my own' - demonstrates that Paula has found a form of expression with which to confront Gregory. For Cavell this is a demonstration that 'the act of speech is hers to define'.$^{57}$

This scene from Gaslight can also be thought of as a pedagogical one. Cameron, as the voice coach, stands alongside Paula. He does not offer her a script, or speak for her, but allows her to find the words that are near to her already. It is as if Cameron is persuaded that Paula's talking will in some way alter her reasoning and her capacity for voicing herself. Cameron does not direct Paula; his voice coaching consists of only the merest of nudges in a certain direction. Another point is significant: the voice coaching is not imposed. Cameron simply asks Paula: 'Will you let me come and talk to you sometime?' Cameron is aware that the process of coming to, finding or recovering the voice is an ongoing process; as he says in the final scene of the film: 'This will be a long night'. Paula first has to recognize not only the denial of her voice, and the denial of herself, but also the enormity of what the journey to recovery of her voice will entail. The night may be a long one; only gradually will the fog (that persists in the film as a metaphor of the fogging of her mind) begin to clear. But some kind of clouding is necessary; being lost, as Thoreau teaches, is the precursor to finding one's way out. What this perhaps demonstrates is that the finding of an academic voice in writing is not the same as adhering to the prescriptions laid down in certain textbook technologies; it is not - or at least it is not only - about this. It is rather an ongoing struggle, a continual loss and recovery of voice. Its development, through writing, is an expression of the worded nature of our individual and political lives.

CODA

${ }^{57}$ Cavell, Contesting Tears, 58. 
One thing that Thoreau's 'experiment in living' at Walden Pond taught him was 'how easily and insensibly we fall into a particular route...How worn and dusty must be the highways of the world, how deep the ruts of tradition and conformity'. ${ }^{58}$ These were Thoreau's reflections as he left Walden Pond. But this trope occurs iteratively throughout Walden; at the outset of his project, he also writes: 'I desire that there be as many different persons in the world as possible; but I would have each one be very careful to find out and pursue his own way, and not his father's, his mother's or his neighbor's instead'. ${ }^{59}$ In thinking of writing in these terms, it is not that students should do as they please, ignoring the conventions in their discipline for endless creativity. Thoreau advocated the value of being lost, but would not deny that some (even well-worn) paths need to be travelled. Just as the possibilities afforded by hoeing rely on the hard labor of prior plowing, so the kind of pedagogy of writing that I am advocating depends upon the hard work of acquiring the very skills and abilities that realize such possibilities in writing. Novice plowers or hoers need to learn their craft. So too, novice writers need guidelines, and these should properly be taught as an induction into the academic community of writers. But academic writing in the university must consist in more than simply the learning of prescribed skills or the mimicking of certain practices. Part of what it is to write, is to recognize that these practices are the ones against which I test my own voice in my community. The tutor too has responsibilities: for her, it is to advocate the value of approaches that do not always settle, and to recognize the pedagogical value in unsettling as a way of finding one's own voice in writing. Such approaches open, rather than restrict, the possibilities of thought.

The rich metaphor of writing as hoeing counters the trend in many of the technologies of writing towards a smoothing of the ground, what Michael Peters, ${ }^{60}$ and elsewhere Marina Garcés, ${ }^{61}$

\footnotetext{
58 Thoreau, Walden, 288.

59 Thoreau, Walden, 65.

60 Michael Peters, "Academic Writing, Genres and Philosophy", Educational Philosophy and Theory, 40, No. 7, (2008): 819 - 831.

${ }^{61}$ Marina Garcés, "The Standardization of Writing. Asphyxia of Philosophical Thought in Academia Today", Open Journal of Philosophy, 3, No. 1, (2013): $39-46$.
} 
call the 'standardizing of academic writing'. Ideas of hoeing, of being lost, and of recovering voice, enable us to focus again on what it is to write, and to be a writer. Writing-as-hoeing rejects the demarcation of writing as a unit of production, an output for rating, evaluation, or assessment against criteria, where writing is reduced to what is effective for the communication of findings. It foregrounds instead our responsibility to, and for our words, and the educative possibilities of being and becoming a writer. In a recent paper on writing in academia, Marina Garcés writes about what she calls the asphyxia, the stifling of thought that the standardisation of academic writing breeds. What (good) writing should be (and here she is considering writing in philosophy) is 'violent and fecund'; she writes:

It is violent because it attacks the very roots of what is constituted. It questions what we are and what we know, what we value and what we purport. It is fecund because it opens up new relations and new ways of seeing and speaking, where once it was only possible to perpetuate what already existed. In brief, it offers new approximations to what makes us live. ${ }^{62}$

\footnotetext{
${ }^{62}$ Garcés, "Standardization", 42.
} 